\title{
PROFITABILITY OF CULTIVATION OF SWEET LUPINE AND FODDER PEA IN COMPARISON TO SELECTED WINTER CEREALS
}

\author{
IRENA AUGUSTYŃSKA \\ ARKADIUSZ BĘBENISTA
}

\begin{abstract}
The subsidies for legumes introduced in 2010 resulted in an increase in their cultivation area, including the area of sweet lupine and fodder pea. The cultivation of lupine is usually carried out on soils of the rye complex, similarly to winter rye, while the cultivation of peas - on soils of the wheat complex, like winter wheat. Due to similar soil requirements, legumes compete with cereals for the arable land. However, the cultivation of the former is not considered to be very profitable, even after including direct subsidies for cultivation. The purpose of the paper was to determine the production and economic results from the cultivation of the abovementioned legumes and cereals and to compare the profitability of cultivation of sweet lupine in relation to winter rye and fodder pea in relation to winter wheat on selected individual farms in Poland in the years 2015-2017. Profitability of cultivation of the plants was determined primarily using the profitability index of production, which is a percentage relation of the total value of production (excluding direct subsidies) to the total costs. The measure of profitability was also the income from activity without subsidies and income from activity after including subsidies. In the research, we used data from the AGROKOSZTY system, the Polish FADN system and the Central Statistical Office. Vertical and horizontal analysis of the results was used. It was shown that on average in the years 2015-2017, on farms participating in the study of considered plants, the profitability of lupine cultivation, expressed by profitability index, was lower than that of rye, and pea cultivation was slightly higher than that of wheat.
\end{abstract}

\footnotetext{
Irena Augustyńska, BEng, MSc, Institute of Food and Agricultural Economics- National Research Institute, Department of Agricultural and Horticultural Economics; ul. Świętokrzyska 20, 00-002 Warsaw, Poland (Irena.Augustynska@ierigz.waw.pl). ORCID iD: 0000-0002-4774-6382.

Arkadiusz Bębenista, BEng, MSc, Masovian Agricultural Advisory Center in Ostrołęka, Poland. Poviat Agricultural Advisory Complex in Maków Mazowiecki; ul. Bazar 15, 06-200 Maków Mazowiecki (Arkadiusz.Bebenista@modr.mazowsze.pl). ORCID iD:0000-0002-1999-9112.
} 
In addition, the first income category, which is the gross margin (difference in total production value and direct costs), and one of the last-income from activity without subsidies (difference in total production value and total costs) proved to be in the case of lupine and peas cultivation relatively low compared to cereals competing with them for the same arable land. However, after taking into account the subsidies, cultivation of legumes was more profitable than cultivation of cereals. Therefore, the incentive for cultivation of legumes certainly provides a possibility for receiving subsidies for the area of their cultivation, and also a possibility for receiving subsidies for greening.

Keywords: legumes, cereals, direct subsidies, profitability of cultivation.

JEL codes: Q12, Q14, Q16, Q18, D24.

\section{Introduction}

Over the last decade, Poland, just like other European Union countries, has been carrying out various types of measures aimed at providing food security with regard to fodder protein quite intensely. What is mainly promoted is an increase in the cultivation area of fodder legumes for fodder seeds (Czerwińska-Kayzer, Jerzak and Krysztofiak, 2016; Jerzak and Krysztofiak, 2017; Jerzak and Mikulski, 2017; Majchrzycki, Pepliński and Baum, 2002). In Poland, the legume most commonly cultivated for this purpose was sweet lupine (which includes all varieties of yellow lupine and most varieties of narrow-leaved lupine), but of great importance was also fodder pea i.e. field pea (Kalinowski, 2018; Stawiński, 2016). Seeds of these plants are a very good source of protein of high biological value. Its content in sweet lupine seeds amounts to $30-44 \%$ of dry matter, and in fodder pea seeds it accounts for $20-26 \%$. They are mainly used for feeding pigs and poultry (Jasińska and Kotecki (ed.), 2003b; Kalinowski, 2018; Rachwał, 2013; ŚmiglakKrajewska, 2012; Święcicki, Rutkowski and Szukała, 2014). Since 2010, farmers from the European Union countries who cultivate legumes have been able to make use of subsidies for their cultivation. Those subsidies were a very important factor determining the increase in the cropped area of those crops (Jerzak, 2014). Another important factor was a possibility of including them in the requirements related to receiving a greening payment. As a result, the area occupied, inter alia, by lupine and field pea started growing gradually. According to available statistical data, in 2017 the area of sweet lupine cultivated for fodder seeds in Poland was 103.28 thousand ha and was by $36.4 \%$ higher than in 2010 , while the area of fodder pea was 18.93 thousand ha and increased 3.1 times. A similar direction of change in the cultivation area of those plants was recorded in the EU-28 countries in total. In 2017, their total area occupied by sweet lupine was 165.31 thousand ha and was higher by $31.7 \%$ than in 2010 , whereas the area occupied by fodder pea amounted to $1,025.79$ thousand ha and increased by $52.6 \%$ when compared to $2011^{1}$.

\footnotetext{
${ }^{1}$ In the case of sweet lupine, there is no Eurostat data for 2011 and in the case of fodder pea there is no Eurostat data for 2010.
} 
In addition, it was determined that in Poland in 2017 the share of cultivation area of sweet lupine and fodder pea in the total cultivation area of fodder legumes for seeds was 51.4 and 9.4\%, respectively, and on individual farms - 50.7 and 9.1\% (Crop..., 2019; Wyniki..., 2012a, 2018).

However, literature sources report that in Poland the cultivation of fodder legumes for fodder seeds is quite often unprofitable. Subsidies granted for their cultivation significantly increase the level of income from these activities, although it is often relatively low and sometimes negative (Bojarszczuk and Podleśny, 2017; Czerwińska-Kayzer et al., 2016; Jerzak, 2014; Jerzak and Mikulski, 2017; Majchrzycki et al., 2002).

Currently, winter wheat is one of the most commonly cultivated cereals in Poland. In 2017, its national cultivation area was 1,949.86 thousand ha. This plant is of great economic importance. Its grain is used as human food and animal feed. Rye is significantly less cultivated than wheat, although its grain is generally used for the same purposes as wheat grain. In 2017, the cultivation area of rye in Poland amounted to 873.22 thousand ha. Back then, the share of cultivation area of winter wheat and winter rye in the national total cereal sowing area was 25.7 and $11.5 \%$, respectively and on individual farms $-23.7 \%$ and $11.9 \%$. It is also worth noting that both in Poland and in the EU-28 countries in total, the cultivation area of winter wheat has remained at a similar level for many years, while the cultivation area of rye has been gradually decreasing (Crop..., 2019; Jasińska and Kotecki (ed.), 2003a; Wyniki..., 2018).

It is known that farmers do not have any control of the air temperature or the level of precipitation on his farm, but it is a farmer who decides which plant will be cultivated on a selected field, specifically on soils of a particular complex. His decision is largely dependent on the potential profitability of a particular production activity. As it has been already mentioned, it is advisable to carry out the cultivation of sweet lupine on soils of the rye complex, just like to the cultivation of winter rye, while the cultivation of fodder pea on soils of the wheat complex, just like the cultivation of winter wheat. Bearing this in mind, this study decided to compare the production and economic results of cultivation of legumes under consideration with the correspondent results of selected cereals with the similar soil requirements.

Finally, the objective of the study was to determine the production and economic results of cultivation of the above-mentioned legumes and cereals and to compare the profitability of cultivation of sweet lupine in relation to winter rye and of cultivation of fodder pea in relation to winter wheat on the selected individual farms in Poland in the years 2015-2017.

\section{Methodology of the studies}

The study mainly presented the production and economic results of pursuing the selected crop production activities on farms, namely, sweet lupine, fodder pea, winter wheat and winter rye in the years 2015-2017. At the beginning, cost-income accounts per 1 ha of cultivation were prepared for each plant. Below please find an outline of such an account. 


\section{Total production value \\ II - Total direct costs \\ III = Gross margin without subsidies \\ IV - Total indirect costs \\ $\mathrm{V}=$ Income from activity without subsidies \\ $\mathrm{VI}+$ Subsidies \\ VII $=$ Income from activity}

The studies used the AGROKOSZTY system ${ }^{2}$ and the Polish FADN system data $^{3}$. Both systems are kept at the Institute of Agricultural and Food Economics National Research Institute (IAFE-NRI) in Warsaw and are partially compatible with each other. This data came from the individual farms located throughout the country and purposively selected for the studies. Depending on the study year, the number of farms included in the groups identified in terms of the examined crop production activity varied from 81 to 167 . Under the AGROKOSZTY system, data on the production level and direct costs ${ }^{4}$ incurred for the specific activities was mainly collected and processed. On the other hand, data on indirect $\operatorname{costs}^{5}$ related to the cultivation of plants covered by the studies was collected and processed under the Polish FADN system. Indirect costs include all costs resulting from the functioning and even only from the existence of a farm. In the calculations presented, they have been divided among various production activities according to the share of specific activity's production value in the total production value of a farm where the analysed activities were pursued. What was used for this purpose, was data from the Polish FADN system database, in which the farms pursuing specific activities examined in the AGROKOSZTY system were identified. The indirect cost division algorithm was applied independently for individual farms and for each examined agricultural production activity. Here, it should be noted that the application of a division key to determine the level of indirect costs associated with the cultivation of a particular plant always entails some imperfections. However, this method has been used at the IAFE-NRI for about 20 years and is accepted, inter alia, by government institutions using the results of studies conducted at the Institute.

As it has been already mentioned, the studies covered the years 2015-2017, but it should be clarified that, under the AGROKOSZTY system, actual data for the selected agricultural production activities can be collected every few years. In the case of sweet lupine and fodder pea, the basis for the previously mentioned

\footnotetext{
${ }^{2}$ AGROKOSZTY - System for Collecting Data on Agricultural Products.

${ }^{3}$ FADN - Farm Accountancy Data Network.

${ }^{4}$ Direct costs of crop production include costs of: seed material, mineral fertilisers, purchased organic fertilisers, plant protection products, growth regulators and other direct costs.

${ }^{5}$ Indirect costs include, inter alia, the cost of electricity, fuel, diesel fuels, agricultural and property taxes, salary for paid labour, rents for land and buildings, interest on loans and depreciation of buildings, machinery and equipment.
} 
2015 calculations was the actual data collected in 2013, and for the calculations covering the years 2016-2017 - data from 2016. This means that for 2015 and 2017 , simulation calculations were carried out for the results of their cultivation under the production and price conditions that occurred in the aforementioned years (Augustyńska and Bębenista, 2019). What was particularly necessary for those calculations, was the most recent data from the Central Statistical Office (GUS), e.g. indicators of changes in the yield and level of grain selling prices of cereals under consideration or purchase prices of agricultural production means. Data from other sources was also used, e.g. the rates of subsidies granted for the cultivation of specific plants under the European Union's Common Agricultural Policy, as published by the Agency for Restructuring and Modernisation of Agriculture.

The analysis included the level of yields and selling prices of sweet lupine and fodder pea seeds as well as of winter wheat and winter rye grain. The level of yields achieved on the farms participating in the studies was additionally described against a background of similar GUS and Eurostat data, but concerning whole Poland and neighbouring European Union countries, whose climatic conditions are similar to those in Poland. The total production value was also assessed, i.e. the total value of the main product (cereal grains and legume seeds), so was the value of those byproducts which have been sold, e.g. cereal straw. It should be clarified that, according to the methodology of studies carried out under the AGROKOSZTY system, the site left after the cultivation of plants in question has not been valued. In addition, the analysis covered the level of direct and indirect costs and selected income categories (gross margin, income from activity without subsidies and income from activity with subsidies) describing the economic results of pursuing each activity.

It is worth mentioning that the study also contains selected information about the farms where actual data for each activity in question was collected. What was also provided was, inter alia, the number of farms, the average area of their utilised agricultural area and the area for the cultivation of plants covered by the studies. Some information was obtained from the Polish FADN system database. Moreover, what was presented was the information collected under the AGROKOSZTY system and regarding the number of hours of total (own and paid) labour inputs incurred for the examined activities, namely for pre-sowing preparation of soil for cultivating specific plants, for soil care work, e.g. weed control and for the harvest and drying of produced products, i.e. cereal grains and legume seeds (Skarżyńska and Abramczuk, 2018).

In addition, the results of several indicators describing the effects of cultivation of plants in question more precisely have been analysed, namely:

- gross margin without subsidies per 100 PLN of direct costs;

- gross margin without subsidies per 1 hour of total labour inputs;

- profitability of cultivation, i.e. the percentage ratio of total production value (calculated without direct subsidies) to total costs, i.e. the total of direct and indirect costs;

- percentage share of total direct subsidies in income from activity. 
The study results were presented mainly in a tabular form, but some were presented graphically. What was presented, were the average results from the groups of farms concerned, on average for the analysed period (2015-2017) and in most cases also for the subsequent study years. The study used the vertical and horizontal analysis of production and economic results.

However, given the fact that the farms for the studies were selected purposively, and the size of study samples was not very large, the results presented cannot be directly identified with the average effects of all Polish individual farms cultivating the plants in question. Nevertheless, these results point to certain relations and trends regarding the effects of their cultivation in the years under consideration.

\section{Study results}

\section{Basic information on the analysed groups of farms cultivating sweet lupine, fodder pea, winter rye and winter wheat}

In the individual years of the 2015-2017 period, the AGROKOSZTY system collected actual data from 115-167 individual farms cultivating sweet lupine, 81-87 farms cultivating fodder pea, 113-119 cultivating winter rye and 140-144 cultivating winter wheat (Table 1).

The farms covered by the studies were considered large under the Polish conditions. Their average utilised agricultural area was quite similar and depending on the study years for the farms cultivating lupine it was 56-68 ha, pea: 56-59 ha, rye: 54-61 ha and wheat: 67-71 ha. On the other hand, the average cultivation area of sweet lupine on the farms pursuing this activity was 6-7 ha, while the area of fodder pea was by about 50\% smaller and stood at 3-4 ha. Areas for the cultivation of cereals were usually much larger. Winter rye was cultivated on an area of 10-12 ha, and winter wheat on an area of 22-24 ha. It was also calculated that, on average, in the analysed period, the average cultivation area of sweet lupine (6.32 ha) was 1.6 times smaller on those farms than the average cultivation area of rye (10.38 ha) while the average cultivation area of fodder pea (3.71 ha) - 6 times smaller than the cultivation area of wheat (22.29 ha). It was also found that throughout the period under consideration, the share of cultivation area of sweet lupine in the total harvest area of farms cultivating was about $11 \%$ and, in the case of pea, rye and wheat, depending on the study year, it was $6-7,18-23$ and $32-33 \%$, respectively.

It is also worth noting that in the years in question, total labour inputs incurred per 1 ha of legumes covered by the studies was 6-7 hours and per 1 ha of analysed cereals - 7-9 hours, while in each case the vast majority (94-98\%) of those inputs were own labour inputs (Table 1). 
Table 1

Basic information on the farms collecting figures on legumes and cereals selected for the studies in the years 2015-2017 (on average in the groups of farms participating in the studies)

\begin{tabular}{|c|c|c|c|c|c|c|c|c|c|}
\hline \multirow{2}{*}{ Wyszczególnienie } & & \multicolumn{3}{|c|}{ Study years } & \multirow{2}{*}{$\begin{array}{c}\text { On } \\
\text { average } \\
\text { in the } \\
\text { years } \\
2015-2017\end{array}$} & \multicolumn{3}{|c|}{ Study years } & \multirow{2}{*}{$\begin{array}{c}\text { On } \\
\text { average } \\
\text { in the } \\
\text { years } \\
2015-2017\end{array}$} \\
\hline & & & & & & & & & \\
\hline & & \multicolumn{4}{|c|}{ sweet lupine } & \multicolumn{4}{|c|}{ winter rye } \\
\hline $\begin{array}{l}\text { Number of farms covered } \\
\text { by the studies }\end{array}$ & & 167 & 115 & 163 & 148 & 113 & 119 & 119 & 117 \\
\hline $\begin{array}{l}\text { Average utilised } \\
\text { agricultural area }\end{array}$ & (ha) & 68.12 & 62.49 & 55.48 & 62.03 & 54.39 & 61.41 & 61.41 & 59.07 \\
\hline $\begin{array}{l}\text { Average cultivation area } \\
\text { of the analysed plant }\end{array}$ & (ha) & 7.14 & 6.07 & 5.75 & 6.32 & 11.52 & 9.81 & 9.81 & 10.38 \\
\hline $\begin{array}{l}\text { Share in the total harvest } \\
\text { area structure of the farm }\end{array}$ & $(\%)$ & 10.8 & 10.5 & 10.8 & 10.7 & 22.5 & 17.6 & 17.6 & 19.2 \\
\hline $\begin{array}{l}\text { Total labour inputs } \\
\text { incurred on the cultivation } \\
\text { of the analysed plant }\end{array}$ & (hour/ha) & 5.8 & 5.5 & 5.8 & 5.7 & 8.8 & 7.4 & 7.4 & 7.9 \\
\hline \multirow[t]{2}{*}{ including: own labour inputs } & $(\%)$ & 93.1 & 97.6 & 98.4 & 96.3 & 95.6 & 97.7 & 97.7 & 96.9 \\
\hline & & \multicolumn{4}{|c|}{ fodder pea } & \multicolumn{4}{|c|}{ winter wheat } \\
\hline $\begin{array}{l}\text { Number of farms covered } \\
\text { by the studies }\end{array}$ & & 87 & 81 & 85 & 84 & 144 & 140 & 140 & 141 \\
\hline $\begin{array}{l}\text { Average utilised } \\
\text { agricultural area }\end{array}$ & (ha) & 58.66 & 56.28 & 59.03 & 57.99 & 71.33 & 66.70 & 66.70 & 68.24 \\
\hline $\begin{array}{l}\text { Average cultivation area } \\
\text { of the analysed plant }\end{array}$ & (ha) & 4.18 & 3.68 & 3.26 & 3.71 & 23.85 & 21.50 & 21.50 & 22.29 \\
\hline $\begin{array}{l}\text { Share in the total harvest } \\
\text { area structure of the farm }\end{array}$ & $(\%)$ & 7.4 & 6.7 & 5.7 & 6.6 & 33.2 & 31.8 & 31.8 & 32.3 \\
\hline $\begin{array}{l}\text { Total labour inputs } \\
\text { incurred on the cultivation } \\
\text { of the analysed plant }\end{array}$ & (hour/ha) & 7.0 & 6.3 & 7.1 & 6.8 & 9.1 & 8.3 & 8.3 & 8.5 \\
\hline including: own labour inputs & $(\%)$ & 96.6 & 95.6 & 97.7 & 96.7 & 94.4 & 95.1 & 95.1 & 94.9 \\
\hline
\end{tabular}

Source: own development based on the AGROKOSZTY system data. 


\section{Production and economic effects of cultivation of analysed plants}

\section{Yields and selling prices of legume seeds and cereal grains}

According to the AGROKOSZTY system data, on average on the farms participating in the studies, the average yield of sweet lupine in the years 2015-2017 was $15.4 \mathrm{dt} / \mathrm{ha}$ and was the same as on average in Poland (Tables 2 and 3).

Table 2

Seed/grain yields from the cultivation of sweet lupine, fodder pea, winter rye and winter wheat in the selected European Union countries in the years 2015-2017

\begin{tabular}{|c|c|c|c|c|c|c|c|c|}
\hline \multirow{2}{*}{ Specification } & \multicolumn{3}{|c|}{ Study years } & \multirow{2}{*}{$\begin{array}{l}\text { On average } \\
\text { in the years } \\
2015-2017\end{array}$} & \multicolumn{3}{|c|}{ Study years } & \multirow{2}{*}{$\begin{array}{l}\text { On average } \\
\text { in the years } \\
2015-2017\end{array}$} \\
\hline & 2015 & 2016 & 2017 & & 2015 & 2016 & 2017 & \\
\hline & \multicolumn{4}{|c|}{ sweet lupine } & \multicolumn{4}{|c|}{ winter rye } \\
\hline Poland & 14.0 & 15.9 & 16.3 & 15.4 & 27.8 & 28.9 & 30.6 & 29.1 \\
\hline Germany & . & . & . & $\mathrm{x}$ & 56.0 & 57.3 & 64.2 & 59.2 \\
\hline $\begin{array}{l}\text { Czech } \\
\text { Republic }\end{array}$ & 14.1 & 19.7 & 15.2 & 16.3 & 49.1 & 49.8 & 49.2 & 49.4 \\
\hline Slovakia & . & . & 11.8 & $\mathrm{x}$ & 36.3 & . & 32.6 & $\mathrm{x}$ \\
\hline \multirow[t]{2}{*}{ Lithuania } & 13.7 & 12.1 & 13.0 & 12.9 & 27.8 & 23.8 & 24.4 & 25.3 \\
\hline & \multicolumn{4}{|c|}{ fodder pea } & \multicolumn{4}{|c|}{ winter wheat } \\
\hline Poland & 19.1 & 21.4 & 23.2 & 21.2 & 47.6 & 47.2 & 51.1 & 48.6 \\
\hline Germany & 44.5 & 36.2 & 44.1 & 41.6 & 79.1 & 71.9 & 82.3 & 77.8 \\
\hline $\begin{array}{l}\text { Czech } \\
\text { Republic }\end{array}$ & 32.7 & 25.8 & 25.1 & 27.9 & 65.0 & 65.7 & 57.7 & 62.8 \\
\hline Slovakia & 30.6 & 25.2 & 23.3 & 26.4 & 55.8 & 59.7 & 48.6 & 54.7 \\
\hline Lithuania & 28.8 & 26.8 & 29.1 & 28.2 & 57.3 & 47.5 & 52.3 & 52.4 \\
\hline
\end{tabular}

(.) - means no data.

(x) - means that the calculation was not reasonable.

Source: own study based on Eurostat data (Crop..., 2019) and GUS data (Wyniki..., 2016, 2017, 2018).

In addition, according to available data on the yield of lupine in the neighbouring European Union (EU) countries, in all years under consideration, its level was higher in our country than in Lithuania and generally lower than in the Czech Republic (Table 3).

When analysing the yield of fodder pea, it was determined that on the farms covered by the studies, on average in the period under consideration, it amounted to $26.4 \mathrm{dt} / \mathrm{ha}$ and exceeded the average yield of this plant in Poland $(21.2 \mathrm{dt} / \mathrm{ha})$ by $24.5 \%$. It was also equal to the yield achieved in Slovakia, but lower than in Germany, the Czech Republic and Lithuania.

It is also worth mentioning that on the farms collecting figures for the AGROKOSZTY system the yield of winter rye in the above-mentioned period was significantly higher than on average in Poland (it was 38.0 in relation to $29.1 \mathrm{dt} / \mathrm{ha}$ on average 
in the country), so was the yield of winter wheat (62.6 in relation to $48.6 \mathrm{dt} / \mathrm{ha}$ ). As regards rye - on the analysed farms and on average in the country - the yield of this cereal was higher than in Lithuania, but lower than in Germany and the Czech Republic. On the other hand, the yield of wheat on the farms under consideration $(62.6 \mathrm{dt} / \mathrm{ha})$ was lower than in Germany and the Czech Republic, but higher than in Lithuania and Slovakia, while on average in the country (48.6 dt/ha) it was lower when compared to the results of all European Union countries neighbouring on Poland (Crop..., 2019; Wyniki..., 2016, 2017, 2018).

The studies conducted under the AGROKOSZTY system also showed that in the considered groups of farms, the yield of sweet lupine was by more than $50 \%$ lower in the individual years of analysis than that of winter rye grain while the seed selling price was by more than $50 \%$ higher. Similar differences were also found when comparing the yield and selling prices of fodder pea and winter wheat, respectively (Table 3 ).

It was also calculated that, on average, in the years 2015-2017, the average yield of lupine seeds (15.4 dt/ha) was by $59.5 \%$ lower than the yield of rye grain $(38.0 \mathrm{dt} / \mathrm{ha})$ on the farms covered by the studies, and the yield of pea $(26.4 \mathrm{dt} / \mathrm{ha})$ was by $57.8 \%$ lower than the yield of wheat $(62.6 \mathrm{dt} / \mathrm{ha})$.

On the other hand, when referring to selling prices of legume seeds, they exceeded, on average in the considered period, the level of grain prices of cereals compared with them by $72.7 \%$ (lupine : rye) and $51.2 \%$ (pea : wheat).

\section{Production value, inputs, costs and revenues}

As already mentioned, the selling prices of lupine seeds were much higher than the prices of rye, just like the prices of pea in relation of prices of wheat grain. However, the three-year average (2015-2017) production value, gross margin and income from activity without subsidies per 1 ha of sweet lupine were much lower when compared to the correspondent results of cultivation of winter rye (by $31.2,31.5$ and $70.5 \%$, respectively) and the identical results of cultivation of fodder pea were much lower when compared to the results of cultivation of winter wheat (by 36.6, 35.0 and 34.4\%, respectively). What was decisive in those cases, were yields of legumes noticeably lower than yields of cereals (Table 3). Here, it is worth mentioning that the information about the lower level of gross margin without subsidies per 1 ha of legumes against cereals compared to them is important, as it is the first element to demonstrate a weaker economic effect of involving land in the conducted production, where the cost-income account does not include subsidies. The economic effect of involving labour inputs was also weaker in this situation. This is indicated by the level of gross margin without subsidies per 1 hour of total labour inputs. It was calculated that for lupine and pea, this indicator was PLN 150.14 and PLN 242.53/h respectively, while for rye and wheat - PLN 158.99 and PLN 297.52/h, respectively. 
Table 3

Production, costs and income from the cultivation of sweet lupine, fodder pea, winter rye and winter wheat in the years 2015-2017 (on average in the groups of farms participating in the studies)

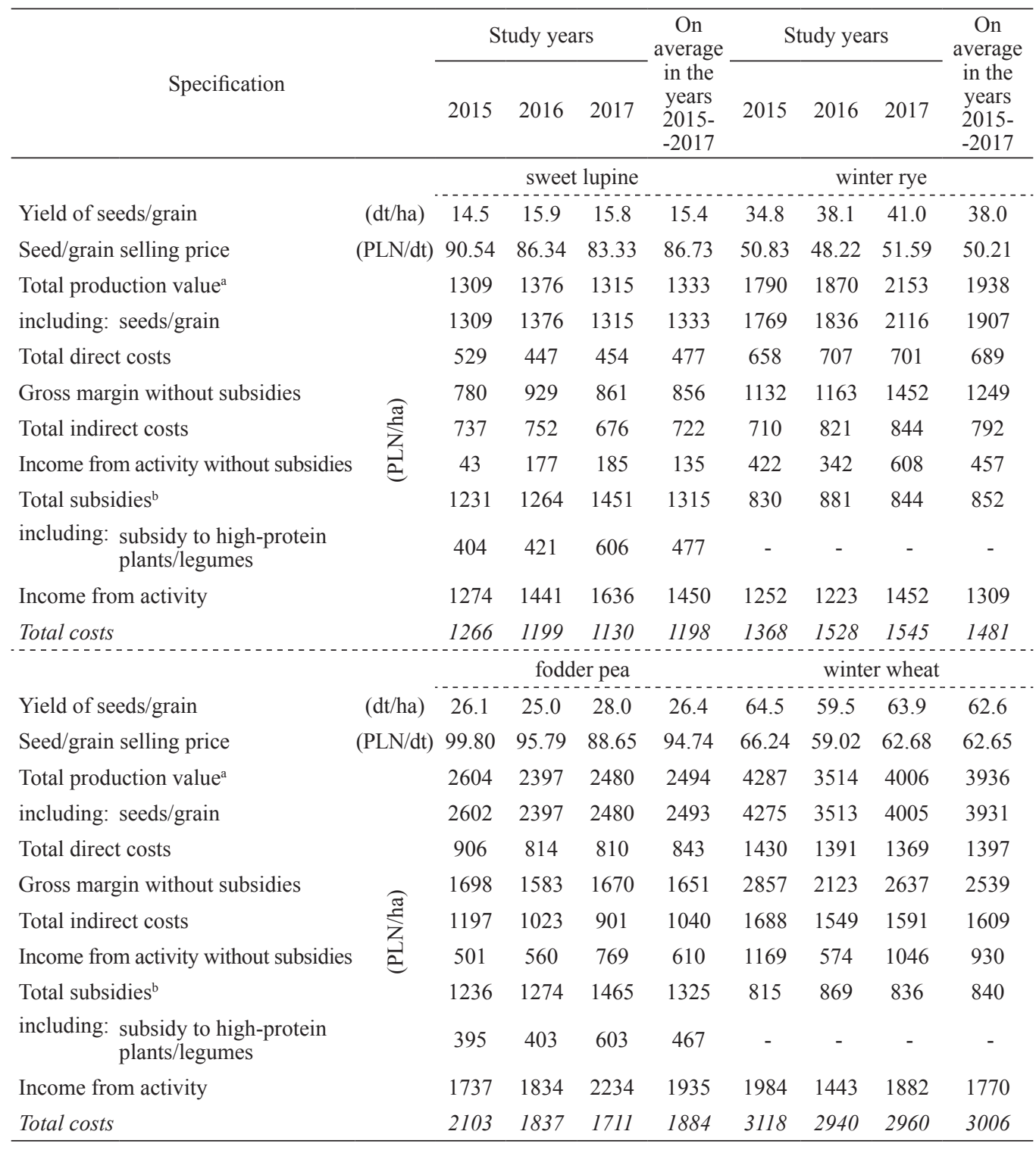

a The total production value includes the value of the main product, e.g. grain and the value of the by-product sold, e.g. straw.

${ }^{\mathrm{b}}$ In the case of cereals, total subsidies include the single area payment, greening payment and additional payment. In the case of legumes in addition to those previously mentioned, subsidies include the payment to the cultivation area of high protein plants (2015-2016) and the payment to the area of legumes for seeds (2017). $(-)$ - means that the phenomenon has not occurred.

Source: own study based on the AGROKOSZTY system data. 
Moreover, in the case of lupine, when compared to rye, the result of the indicator informing about the economic effect of capital involvement, calculated as the gross margin without subsidies per PLN 100 of direct costs (PLN 179.45 in relation to PLN 181.28) was weaker. Only for pea, the level of this indicator (PLN 195.85) was more favourable than that of wheat (PLN 181.75).

Unfavourable for legumes differences between the level of income from activity without subsidies and the corresponding results of cereals compared with them would be even higher but for lower costs of cultivation of legumes. It was determined that, on average in the study years, total costs incurred for the cultivation of 1 ha of lupine were by $19.1 \%$ lower than those associated with the cultivation of rye while costs of cultivation of pea were lower by $37.3 \%$ than those of wheat. The studies show that this fact was determined by both lower direct and indirect costs (Table 4).

Table 4

Costs of cultivation of legumes and cereals selected for the studies in the years 2015-2017 (average in the groups of farms participating in the studies)

\begin{tabular}{|c|c|c|c|c|c|c|c|c|c|}
\hline \multirow{2}{*}{ Specification } & & \multicolumn{3}{|c|}{ Study years } & \multirow{2}{*}{$\begin{array}{c}\text { On } \\
\text { average } \\
\text { in the } \\
\text { years } \\
2015- \\
-2017\end{array}$} & \multicolumn{3}{|c|}{ Study years } & \multirow{2}{*}{$\begin{array}{c}\text { On } \\
\text { average } \\
\text { in the } \\
\text { years } \\
2015- \\
-2017\end{array}$} \\
\hline & & 2015 & 2016 & 2017 & & 2015 & 2016 & 2017 & \\
\hline & & \multicolumn{4}{|c|}{ sweet lupine } & \multicolumn{4}{|c|}{ winter rye } \\
\hline Total costs & & 1266 & 1199 & 1130 & 1198 & 1368 & 1528 & 1545 & 1481 \\
\hline of which: total direct costs & & 529 & 447 & 454 & 477 & 658 & 707 & 701 & 689 \\
\hline including: seed material & & 257 & 224 & 192 & 224 & 109 & 170 & 177 & 152 \\
\hline total mineral fertilisers & & 153 & 119 & 125 & 132 & 427 & 423 & 408 & 419 \\
\hline including: cost of NPK & 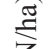 & 153 & 119 & 123 & 132 & 423 & 412 & 397 & 411 \\
\hline plant protection products & 岁 & 106 & 87 & 96 & 96 & 101 & 98 & 100 & 100 \\
\hline total indirect costs & & 737 & 752 & 676 & 722 & 710 & 821 & 844 & 792 \\
\hline of which: indirect actual costs ${ }^{\mathrm{a}}$ & & 341 & 329 & 330 & 333 & 334 & 364 & 377 & 358 \\
\hline depreciation & & 303 & 303 & 259 & 288 & 278 & 325 & 332 & 312 \\
\hline cost of external factors & & 93 & 120 & 87 & 100 & 98 & 132 & 135 & 122 \\
\hline & & \multicolumn{4}{|c|}{ fodder pea } & \multicolumn{4}{|c|}{ winter wheat } \\
\hline Total costs & & 2103 & 1837 & 1711 & 1884 & 3118 & 2940 & 2960 & 3006 \\
\hline of which: total direct costs & & 906 & 814 & 810 & 843 & 1430 & 1391 & 1369 & 1397 \\
\hline including: seed material & & 427 & 318 & 325 & 357 & 198 & 216 & 216 & 210 \\
\hline total mineral fertilisers & & 294 & 290 & 288 & 291 & 808 & 778 & 750 & 779 \\
\hline including: cost of NPK & 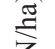 & 284 & 283 & 278 & 282 & 772 & 746 & 718 & 745 \\
\hline plant protection products & 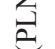 & 179 & 175 & 186 & 180 & 370 & 334 & 339 & 348 \\
\hline total indirect costs & & 1197 & 1023 & 901 & 1040 & 1688 & 1549 & 1591 & 1609 \\
\hline of which: indirect actual costs ${ }^{\mathrm{a}}$ & & 517 & 436 & 401 & 451 & 797 & 682 & 706 & 728 \\
\hline depreciation & & 421 & 390 & 336 & 382 & 606 & 591 & 603 & 600 \\
\hline cost of external factors & & 259 & 197 & 164 & 207 & 285 & 276 & 282 & 281 \\
\hline
\end{tabular}

${ }^{a}$ Excluding the cost of external factors.

Source: own study based on the AGROKOSZTY system data. 
It was calculated that, on average in the period under consideration, the level of direct costs of cultivation of sweet lupine against winter rye was lower by $30.8 \%$ and of direct costs of cultivation of fodder pea against winter wheat - by $39.7 \%$. This evidences the lower legume production intensity when compared to cereals. The analysis showed that this was mainly the result of incurring lower costs of mineral fertilisers for legumes than for cereals compared to them. As regards indirect (total) costs, they were lower for legumes by $8.8 \%$ (lupine : rye) and by $35.4 \%$ (pea : wheat) respectively, which was similarly determined by indirect actual costs (excluding the cost of external factors) and depreciation (Table 4).

As it is commonly known, the normal growth and development of cultivated plants requires the provision of adequate amounts of minerals that can be divided into macro- and micronutrients. The three basic macronutrients necessary for these processes are nitrogen $(\mathrm{N})$, phosphorus $(\mathrm{P})$ and potassium $(\mathrm{K})$, so relatively large amounts of them are used. The studies show that, on average in the analysed period, 45 and $98 \mathrm{~kg}$ of NPK were consumed, respectively, per 1 ha of sweet lupine and fodder pea, significantly less than for analysed cereals (rye $-126 \mathrm{~kg}$, wheat $240 \mathrm{~kg}$ ). This difference resulted mainly from the fact that nitrogen doses used for legumes were significantly smaller than those used for cereals (Fig. 1). This, in turn, resulted from the ability of legume roots to co-exist with rhizobia assimilating free atmospheric nitrogen from the air.

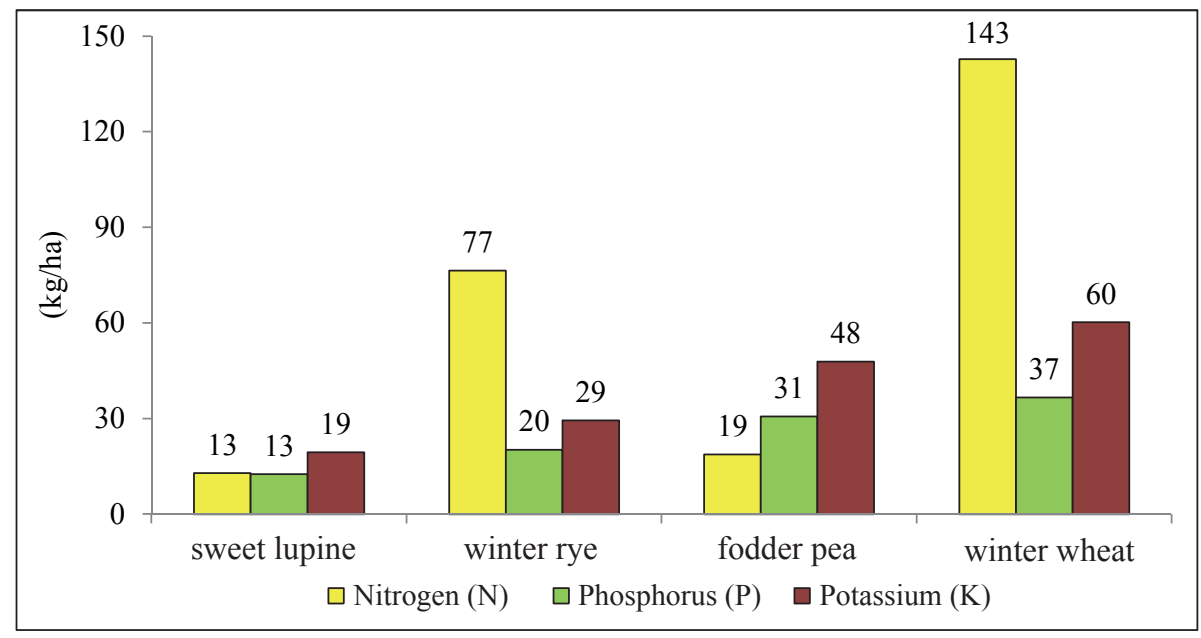

Fig. 1. Consumption of NPK fertilisers - in kg of pure fertiliser components - for the cultivation of legumes and cereals selected for the studies, on average in the years 2015-2017 (in the groups of farms participating in the studies).

Source: own study based on the AGROKOSZTY system data.

At this point, it is worth mentioning that an excessive nitrogen dose applied to legumes can contribute to their uneven ripening, which makes it difficult to harvest seeds and, as a consequence, can result in losses. Especially lupine is 
particularly sensitive to nitrogen over-fertilisation (Jasińska and Kotecki (ed.), 2003b). In addition, legumes react weaker to phosphorus and potassium fertilisation, as thanks to the strongly developed root system they can derive these nutrients from soil (Jerzak, 2017). In turn, fertilisation, in particular mineral one, is a very important factor determining the yielding of cereals, e.g. the application of appropriate nitrogen doses for wheat results in the proper number and quality of grains in the ear (Jasińska and Kotecki (ed.), 2003a).

On average, in the years 2015 and 2017, the total cost of NPK fertilisers used for sweet lupine and fodder pea was PLN 132 and PLN 282/ha, respectively (Table 4) and was lower than in the case of cereals competing with them for the same agricultural land (rye and wheat), by 67.9 and $62.2 \%$, respectively. It is also worth noting that the cost of NPK accounted for $96-99 \%$ of the total cost of mineral fertilisers consumed for all plants covered by the studies.

It was also found that per $1 \mathrm{~kg}$ of NPK fertilisers used for the cultivation of lupine and peas, there were respectively 34 and $27 \mathrm{~kg}$ seeds produced, and for the cultivation of rye and wheat - a little less, as 30 and $26 \mathrm{~kg}$ grain.

However, when considering the results of cultivation of plants discussed in this study, it should be remembered that direct subsidies were granted for them in the years 2015-2017. Throughout the study period, they included the single area payment, greening payment and additional payment. In addition, in the case of sweet lupine and fodder pea, in the years 2015-2016 they also included the payment to the cultivation area of high-protein plants, and in 2017 - payment to the area of legumes for seeds. The calculations show that, on average in the three-year period under consideration, the share of total subsidies in income from the cultivation of sweet lupine was $90.7 \%$ on the analysed farms and in income from the cultivation of fodder pea $-68.5 \%$, with 65.1 and $47.5 \%$, for winter rye and winter wheat respectively. As a result, for lupine, this share was by $25.6 \mathrm{pp}$ higher than in income from the cultivation of rye, and in the case of pea - by 21.0 p.p. higher than income from the cultivation of wheat (Fig. 2).

It should also be mentioned that, on average, in the period under consideration, total subsidies increased the level of income from activity as follows: from 1 ha of cultivation of lupine - 10.7 times, from 1 ha of cultivation of pea-3.2-times, and from 1 ha of cultivation of rye and wheat -2.9 and 1.9 times, respectively.

The payment to the cultivation area of lupine and pea was a significant part of total subsidies granted for them. In the first two study years, depending on the analysed plant, this payment accounted for $32-33 \%$ of total subsidies and for around $41 \%$ in the third study year. Finally, these payments largely determined that, on average throughout the study period, income from activity from the cultivation of sweet lupine (PLN 1,450/ha) was by $10.8 \%$ higher than corresponding income from winter rye (PLN 1,309/ha) while income from the cultivation of fodder pea (PLN 1,935 ha) was by $9.3 \%$ higher than income from the cultivation of winter wheat (PLN 1,770/ha). It was determined that the absence of subsidies granted for the cultivation area of legumes would be a reason for which income from 1 ha of lupine in the considered three-year period would stand at PLN 973 and would be by $25.7 \%$ lower than income from 1 ha of rye, while income from 1 ha of pea would amount to PLN 1,468 and would be by $17.1 \%$ lower than in the case of wheat. 


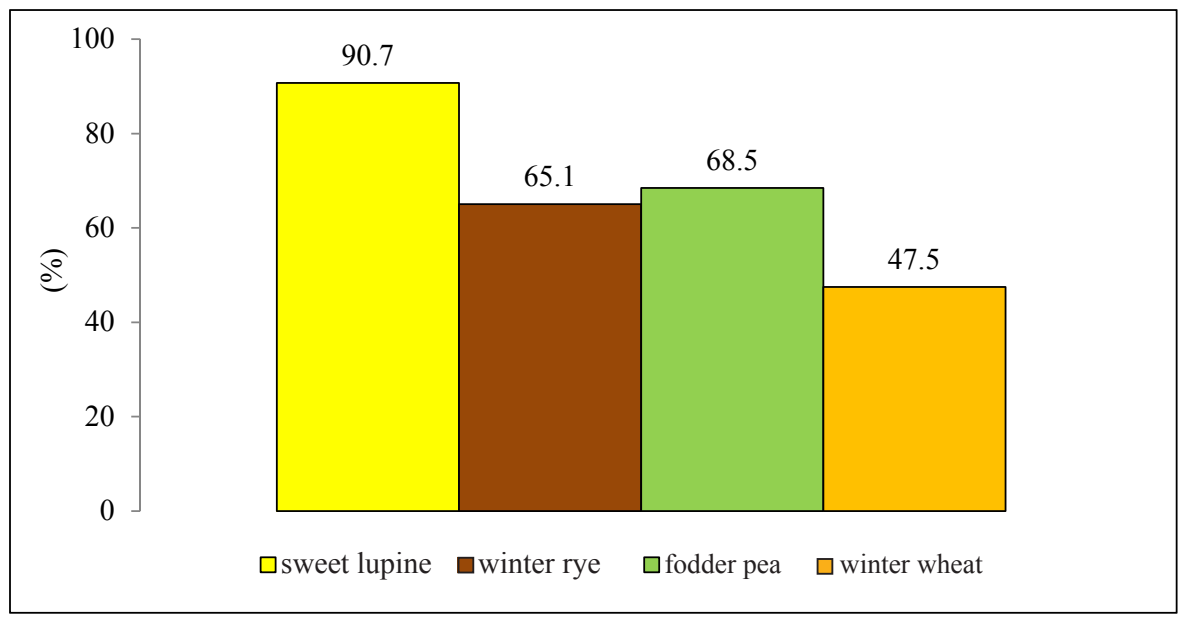

Fig. 2. Total share of subsidies in income from activity from the cultivation of legumes and cereals selected for the studies, on average in the years 2015-2017 (in the groups of farms participating in the studies).

Source: own study based on the AGROKOSZTY system data.

It is also worth paying attention to income from activity achieved in the individual study years, and particularly in 2015. The calculations show that in this year income in the case of lupine was only by $1.8 \%$ higher than income from the cultivation of rye, although in the subsequent study years the difference in favour of lupine was 17.8 and $12.7 \%$, respectively. Moreover, for pea, the level of income was even lower in 2015 - by $12.5 \%$ in relation to income from wheat, although in the following two years it was higher by 27.1 and $18.7 \%$, respectively. These "not much typical", as for 2015 , results of comparing income from crop production activities competing with each other for the same agricultural land result from the agrometeorological conditions which at that time were particularly unfavourable for the cultivation of legumes. In the summer of 2015, Poland was affected by agricultural drought which covered $75.1 \%$ of the cultivation area of legumes and only $4.2 \%$ of the cultivation area of winter cereals (System..., 2015).

The consequence of the above-mentioned situation was that, according to the GUS data, in 2015, the average domestic yield of sweet lupine seeds $(14.0 \mathrm{dt} / \mathrm{ha})$ and of fodder pea seeds (19.1 dt/ha) was lower than on average in the five-year period of 2010-2014 - by 14.1 and $6.4 \%$ respectively, while both the yield of winter rye $(27.8 \mathrm{dt} / \mathrm{ha})$ and of winter wheat $(47.6 \mathrm{dt} / \mathrm{ha})$ were slightly higher - by 0.7 and 3.5\%, respectively (Wyniki..., 2012a, 2012b, 2013, 2014, 2015, 2016). In 2015, when compared to the following two years, yields of legumes obtained on the farms collecting data for the AGROKOSZTY system were also not high. In addition, the analysis showed that in 2015 the cultivation of sweet lupine and fodder pea entailed much higher total costs than in 2016 and 2017. Finally, in 2015, when compared to the years 2016-2017, the lowest income from activity without subsidies was 
obtained from 1 ha of legumes under consideration. This was translated into the lowest level of income with subsidies (Table 3 ) and therefore to the lowest profitability of pursuing those activities.

The last of the above-mentioned facts is evidenced by the profitability index of cultivation of plants under consideration. In 2015, the profitability of cultivation of both lupine and pea, measured by this index, was much lower than in the following two years. For lupine, it was $103.4 \%$ against $114.8 \%$ and $116.4 \%$, respectively, and for pea, it was $123.8 \%$ against 130.5 and $144.9 \%$. However, on average in the years 2015-2017, the result of this index for lupine was $111.3 \%$, while for pea it was higher by $21.1 \mathrm{pp}$, standing at $132.4 \%$ (Fig. 3).

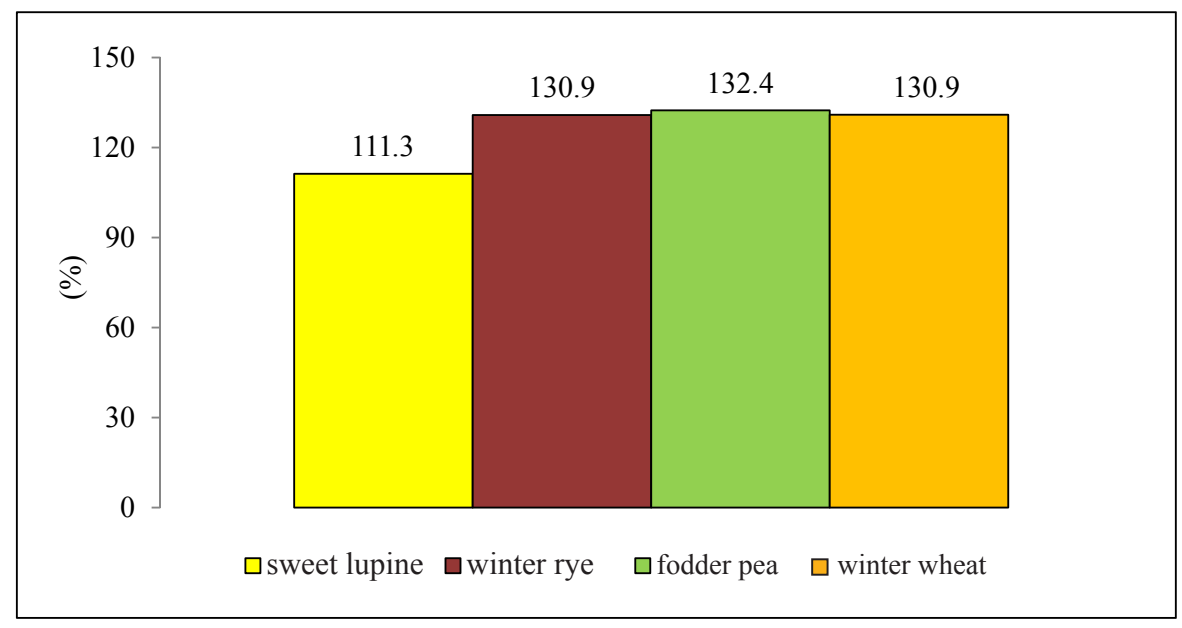

Fig. 3. Profitability of cultivation of legumes and cereals selected for the studies, on average in the years 2015-2017 (in the groups of farms participating in the studies).

Source: own study based on the AGROKOSZTY system data.

It is worth mentioning that, on average, throughout the considered period, as well as in the individual study years, the profitability index of cultivation of lupine was lower than that of rye, whereas in the case of pea - generally higher than of wheat (except in 2015). It was also determined that, on average in the years 2015-2017, the profitability index of cultivation of both cereals in question was the same $-130.9 \%$, although it differed noticeably in the individual years.

In 2015 , for rye, the index was $130.8 \%$, followed by 122.4 and $139.4 \%$ in the following two years. For wheat, it was $137.5 \%$ in 2015 and was lower by 18.0 and $2.2 \mathrm{pp}$ in 2016 and 2017, respectively.

It is also interesting that, on average, in the period under consideration, the potential payment of own labour inputs (ratio of income from activity to own labour inputs) incurred for the cultivation of legumes was higher than for cereals compared to them. For lupine and pea, it was PLN 263.67 and PLN 293.14/hour, respectively, and for rye and wheat it was PLN 172.24 and PLN 218.49/hour respectively. Here, 
an important fact was that income from activity (including subsidies) from the cultivation of legumes was significantly higher than from cereals compared to them and labour inputs incurred were significantly lower.

Table 5

Production, costs and income from the cultivation of sweet lupine, fodder pea, winter rye and winter wheat on average in the years 2015-2017 (on farms with selected cultivation scales of analysed plants)

\begin{tabular}{|c|c|c|c|c|c|}
\hline \multirow{2}{*}{ Specification } & & \multicolumn{2}{|c|}{ Cultivation scale: $1-3$ ha } & \multicolumn{2}{|c|}{ Cultivation scale: $6-8$ ha } \\
\hline & & sweet lupine & winter rye & fodder pea & winter wheat \\
\hline Number of farms in the studies & & 35 & 37 & 21 & 41 \\
\hline Utilised agricultural area & (ha) & 34.22 & 26.89 & 80.49 & 34.28 \\
\hline Cultivation area & (ha) & 1.51 & 2.55 & 7.08 & 6.42 \\
\hline Yield of seeds/grain & (dt/ha) & 15.2 & 33.9 & 26.3 & 52.5 \\
\hline Seed/grain selling price & (PLN/dt) & 99.64 & 50.06 & 93.17 & 62.33 \\
\hline Total production value & & 1513 & 1707 & 2440 & 3291 \\
\hline including: seeds/grain production & & 1513 & 1694 & 2438 & 3280 \\
\hline Total direct costs & & 543 & 590 & 851 & 1160 \\
\hline including: seed material & & 251 & 138 & 369 & 203 \\
\hline total mineral fertilisers & & 171 & 338 & 288 & 652 \\
\hline plant protection products & & 100 & 84 & 180 & 271 \\
\hline Gross margin without subsidies & $\sum^{z}$ & 970 & 1117 & 1589 & 2132 \\
\hline Total indirect costs & $\underline{e}$ & 665 & 693 & 990 & 1367 \\
\hline $\begin{array}{l}\text { Income from activity without } \\
\text { subsidies }\end{array}$ & & 305 & 425 & 599 & 765 \\
\hline Total subsidies & & 1367 & 893 & 1293 & 891 \\
\hline $\begin{array}{l}\text { including: } \\
\text { plants/legumes }\end{array}$ & & 476 & - & 453 & - \\
\hline Income from activity & & 1672 & 1318 & 1892 & 1656 \\
\hline Total costs & & 1208 & 1282 & 1841 & 2527 \\
\hline Total labour inputs & hour & 9.8 & 10.2 & 6.1 & 10.0 \\
\hline including own labour inputs & $(\%)$ & 98.0 & 97.1 & 95.1 & 98.0 \\
\hline Profitability of cultivation & $(\%)$ & 125.3 & 133.1 & 132.5 & 130.3 \\
\hline
\end{tabular}

$(-)$ - means that the phenomenon has not occurred.

Source: own study based on the AGROKOSZTY system data.

The study also presents the basic production and economic results from the cultivation of legumes under consideration in relation to cereals compared to them and cultivated on a similar area as legumes (Table 5). The available data allowed to select for the studies those farms, where, on average in the years 2015-2017, the average cultivation area of lupine and rye was between 1-3 ha and the cultivation area of pea and wheat $-6-8$ ha. The study results showed that, on average in the considered period, the level of production, gross margin (without subsidies) and in- 
come from activity without subsidies was lower for analysed legumes in relation to cereals, despite lower costs of cultivation. The profitability of cultivation of lupine in relation to rye was also lower, which was expressed by the profitability index, while the profitability of cultivation of pea was higher when compared to wheat. The lower level of total costs resulted from both lower direct costs (which points to the lower production intensity of legumes) and indirect costs. However, significantly higher total subsidies for the cultivation of legumes (as a result of including subsidies to the cultivation area) determined higher income from these activities than for cereals compared to them.

To sum up, the level of income categories which did not include direct subsidies (gross margin and income from activity) was lower in the case of legumes (lupine and pea) than in the case of cereals (rye and wheat, respectively). This, in turn, indicates the lower profitability of cultivation of the former, as expressed by these categories. However, the inclusion of subsidies in income from activity has reversed this situation. As a result, on the farms covered by the studies with the similar cultivation scale of production activities compared to each other, despite significant differences in the utilised agricultural area, the directions of changes in the economic results of these activities are generally convergent with the previously presented study results on whole communities collecting data on those activities.

\section{Summary and conclusions}

Sweet lupine is usually cultivated on soils of the rye complex, just like winter rye, while fodder pea is cultivated on soils of the wheat complex, just like winter wheat. This means that these legumes compete with these cereals for arable land: lupine with rye and pea with wheat.

The studies showed that, on average in the years 2015-2017, on the farms covered by the AGROKOSZTY system studies, due to lower yields of lupine and pea, the total production value from 1 ha of their cultivation was noticeably lower in relation to rye and wheat. The gross margin (without subsidies) per 1 ha of cultivation and income from activity without subsidies were also lower, although the level of total direct and indirect costs was also lower.

Furthermore, it was concluded that differences at the level of gross margin (without subsidies) and income from activity without subsidies from the cultivation of legumes and similar results of cereals compared with them would be even higher (to the detriment of sweet lupine and fodder pea) but for the lower level of costs of cultivation of legumes, both direct and indirect. The greatest impact on the differentiation of the level of direct costs was that of the cost of nitrogen fertilisers which was significantly lower for legumes. This was mainly due to the lower consumption of nitrogen fertilisers. As regards the lower level of indirect costs (in total), it was similarly determined by indirect actual costs (excluding the cost of external factors) and depreciation.

Direct subsidies were granted to the cultivation of all plants in question. In the case of lupine and pea, additional production-oriented subsidies could be received. In view of this, it can be concluded without any doubt that it was precisely 
due to the inclusion of subsidies for legumes that, on average in the adopted study period, income from activity from 1 ha of lupine clearly exceeded similar income from rye, just like income from 1 ha of fodder pea exceeded income from wheat. This means that ultimately the cultivation of legumes was more profitable than of cereals compared with them. These payments were a great incentive for farmers to cultivate sweet lupine or fodder pea instead of cereals compared with them. Another incentive was the possibility of meeting the requirement for receiving the greening payment. However, it should be borne in mind that legume seeds are primarily a good source of protein-rich feed components. It is therefore advisable to maintain subsidies to the cultivation area of these plants under the Common Agricultural Policy applicable after 2020. 


\section{References}

Augustyńska, I., Bębenista, A. (2019). Produkcja, koszty i dochody z wybranych produktów rolniczych w latach 2017-2018 (wyniki rachunku symulacyjnego). Warszawa: IERiGŻ-PIB.

Bojarszczuk, J., Podleśny, J. (2017). Ocena ekonomiczna uprawy mieszanki łubinu wąskolistnego z pszenżytem jarym. Fragm. Agron., No. 34(1), p. 19-29.

Crop production in EU standard humidity. (2019) Eurostat - Data Explorer. Retrieved from: appsso.eurostat.ec.europa.eu/nui/print.do (access date: 29.07.2019).

Czerwińska-Kayzer, D., Jerzak, M.A., Krysztofiak, P. (2016). Rynek rodzimych roślin strączkowych w Polsce a bezpieczeństwo kraju w zakresie białka roślinnego. Zagadnienia Doradztwa Rolniczego, No. 4, p. 26-36.

GUS (2012a). Wyniki produkcji roślinnej w 2010 r. Warszawa: GUS.

GUS (2012b). Wyniki produkcji roślinnej w 2011 r. Warszawa: GUS.

GUS (2013). Wyniki produkcji roślinnej w 2012 r. Warszawa: GUS.

GUS (2014). Wyniki produkcji roślinnej w 2013 r. Warszawa: GUS.

GUS (2015). Wyniki produkcji roślinnej w 2014 r. Warszawa: GUS.

GUS (2016). Wyniki produkcji roślinnej w 2015 r. Warszawa: GUS.

GUS (2017). Wyniki produkcji roślinnej w 2016 r. Warszawa: GUS.

GUS (2018). Wyniki produkcji roślinnej w 2017 r. Warszawa: GUS.

Jasińska, Z., Kotecki, A. (ed.). (2003a). Szczegółowa uprawa roślin. Vol. I, $2^{\text {nd }}$ edition, corrected and supplemented. Wrocław: Wydawnictwo Akademii Rolniczej we Wrocławiu.

Jasińska, Z., Kotecki, A. (ed.). (2003b). Szczegółowa uprawa roślin. Vol. II, $2^{\text {nd }}$ edition, corrected and supplemented. Wrocław: Wydawnictwo Akademii Rolniczej we Wrocławiu.

Jerzak, M.A. (2014). Możliwości restytucji rynku rodzimych roślin strączkowych na cele paszowe w Polsce. Roczniki Naukowe SERiA, Vol. XVI, Issue 3, p. 104-109.

Jerzak, M.A. (2017). Czy warto nawozić rośliny strączkowe? Rolnicze ABC, No. 2(317).

Jerzak, M.A., Krysztofiak, P. (2017). Narodowy cel wskaźnikowy jako czynnik rozwoju rynku rodzimego białka roślinnego. Roczniki Naukowe SERiA, Vol. XIX, Issue 3, p. 92-97.

Jerzak, M.A., Mikulski W. (2017). Znaczenie dopłat do produkcji roślin strączkowych w odbudowie rynku rodzimych surowców białkowych pochodzenia roślinnego w Polsce. Zagadnienia Ekonomiki Rolnej, No. 2(351), p. 152-163.

Kalinowski, M. (2018). Lista zalecanych odmian łubinu żółtego. Tygodnik poradnik rolniczy. Retrieved from: https:/www.tygodnik-rolniczy.pl/articles/uprawa/lista-zalecanych-odmian-lubinu -zoltego/?page=1\#lead (access date: 26.02.2019).

Majchrzycki, D., Pepliński, B., Baum, R. (2002). Opłacalność uprawy roślin strączkowych jako alternatywnego źródła białka. Roczniki Akademii Rolniczej w Poznaniu, CCCXLIII, Ekon. 1, p. $129-136$.

Rachwał, A. (2013). Nasiona roślin motylkowatych jako pasza dla drobiu. Retrieved from: http://www.portalhodowcy.pl/307-nasiona-roslin-motylkowatych-jako-pasza-dla-drobiu (access date: 27.07.2019).

Skarżyńska, A., Abramczuk, Ł. (2018). Wyniki ekonomiczne wybranych produktów rolniczych w 2017 roku. Warszawa: IERiGŻ-PIB.

Stawiński, S. (2016). Łubin wąskolistny - gatunek niewykorzystanych możliwości. Agro Serwis, p. 29-34.

System Monitoringu Suszy Rolniczej. Komunikaty odnośnie wystapienia warunków suszy w Polsce. Rok 2015 (2015). Puławy: IUNG-PIB. 
Śmiglak-Krajewska, M. (2012). Ekonomiczne uwarunkowania uprawy oraz wykorzystania na cele paszowe roślin strączkowych uprawianych w Polsce. Roczniki Naukowe SERiA, Vol. XIV, Issue 3, p. 411-415.

Święcicki, W., Rutkowski, A., Szukała, J. (2014). Quo vadis lupine. Conference „Łubin we współczesnym rolnictwie”. Kudowa Zdrój, p. 9-10. 


\title{
OPŁACALNOŚĆ UPRAWY ŁUBINU SŁODKIEGO I GROCHU PASTEWNEGO NA TLE WYBRANYCH ZBÓŻ OZIMYCH
}

\begin{abstract}
Abstrakt
Wprowadzone w 2010 roku dopłaty do roślin straczkowych skutkowaty zwiększeniem ich powierzchni uprawy, w tym areatu tubinu słodkiego i grochu pastewnego. Uprawa tubinu prowadzona jest na ogót na glebach kompleksu żytniego, analogicznie jak żyta ozimego, natomiast uprawa grochu - na glebach kompleksu pszennego, tak jak pszenicy ozimej. Ze względu na podobne wymagania glebowe rośliny straczkowe konkuruja zatem ze zbożami o grunty orne. Jednak uprawa tych pierwszych często uważana jest za mało opłacalna, nawet po uwzględnieniu przystugujących do ich uprawy dopłat bezpośrednich. Celem pracy byto określenie wyników produkcyjno-ekonomicznych z uprawy wspomnianych powyżej roślin straczkowych i zbożowych oraz porównanie optacalności uprawy tubinu stodkiego wodniesieniu do żyta ozimego oraz grochu pastewnego $w$ odniesieniu do pszenicy ozimej $w$ wybranych gospodarstwach indywidualnych $w$ Polsce w latach 2015-2017. Optacalność uprawy rozpatrywanych roślin określono przede wszystkim przy wykorzystaniu wskaźnika opłacalności produkcji, będacego procentowa relacja wartości produkcji ogółem (bez uwzględniania dopłat bezpośrednich) do kosztów ogółem. Miara opłacalności byt też dochód z działalności (bez dopłat, jak i po ich uwzględnieniu). W badaniach wykorzystano m.in. dane systemu AGROKOSZTY, systemu Polski FADN oraz GUS. Przeprowadzono pionowa i pozioma analize wyników. Wykazano, ze przeciętnie w latach 2015-2017 $w$ gospodarstwach uczestniczacych $w$ badaniach poszczególnych z rozpatrywanych roślin opłacalność uprawy tubinu, wyrażona wskaźnikiem opłacalności, była niższa niż żyta, a uprawy grochu - trochę wyższa niż pszenicy. Ponadto zarówno pierwsza kategoria dochodowa, która jest nadwyżka bezpośrednia (różnica wartości produkcji ogółem i kosztów bezpośrednich), jak i jedna z ostatnich-dochód $z$ działalności bez dopłat (różnica wartości produkcji ogółem i kosztów ogółem) okazaty się w przypadku uprawy tubinu i grochu relatywnie niskie w porównaniu ze zbożami konkurujacych z nimi o te same grunty rolne. Jednak po doliczeniu dopłat uprawa straczkowych była bardziej opłacalna niż uprawa zbóż. Zatem możliwość otrzymania dopłat do powierzchni uprawy roślin straczkowych byta z pewnościa zachętą do ich uprawy, a dodatkowo-możliwość spetnienia wymogu do uzyskania płatności z tytułu zazielenienia.
\end{abstract}

Słowa kluczowe: rośliny strączkowe, zboża, dopłaty bezpośrednie, opłacalność uprawy.

Accepted for print: 18.06 .2020$.

Unless stated otherwise all the materials on the website are available under the Creative Commons Attribution 4.0 International license.

Some rights reserved to the Institute of Agricultural and Food Economics - National Research Institute.

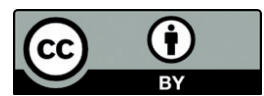

